\title{
Internal phosphorus loading due to sediment anoxia in shallow areas: implications for lake aeration treatments
}

\author{
Olga Tammeorg ${ }^{1,2}\left[\right.$ Gertrud Nürnberg $^{3} \cdot$ Juha Niemistö $^{1} \cdot$ Marina Haldna $^{2} \cdot$ Jukka Horppila $^{1}$
}

Received: 2 October 2019 / Accepted: 17 April 2020 / Published online: 2 May 2020

(c) The Author(s) 2020

\begin{abstract}
Shallow lake sediments may be anoxic despite overlying aerated water. In the current study, we aimed to ascertain the contribution of shallow areas to internal phosphorus (P) loading due to sediment anoxia in stratifying lakes. Moreover, we analyzed relationships of the key water quality variables with internal P loading due to sediment anoxia originating solely from stratifying areas $\left(\mathrm{IP}_{\mathrm{obs}}\right)$ and that accounting also for the shallow areas $\left(\mathrm{IP}_{\text {pred }}\right)$ for a set of Finnish lakes, including intentionally aerated and non-aerated lakes. Finally, using a broader set of lakes worldwide, we established a specific combination of lake characteristics that predict sediment $\mathrm{P}$ release due to sediment anoxia and linked it to the practices of aeration. Our results showed that shallow lake areas (a difference between $\mathrm{IP}_{\text {pred }}$ and $\mathrm{IP}_{\mathrm{obs}}$ ) contributed about half of the total $\mathrm{P}$ flux due to sediment anoxia. While all of the studied water quality variables related significantly to $\mathrm{IP}_{\text {pred }}$, only the concentration of total phosphorus (TP) in the near-bottom water layer related significantly to $\mathrm{IP}_{\mathrm{obs}}$. This indicates the key importance of $\mathrm{P}$ release of shallow areas for water quality. The concentrations of TP in the surface water layer and chlorophyll $a$ were significantly dependent on $\mathrm{IP}_{\text {pred }}$ irrespectively of the treatment (aerated lakes or not). P supply from shallow areas may affect aeration effectiveness in stratifying lakes. $\mathrm{IP}_{\text {pred }}$ was found to be dependent on the specific combination of lake characteristics (including mean and maximum depth, lake and catchment area, external P loading) PC3, driven mainly by external P loading. Hence, external load reduction should be considered as the first priority in lake water quality management. By linking the dependence of $\mathrm{IP}_{\text {pred }}$ on PC3 to aeration practices, we determined the conditions that promise increased effectiveness of aeration treatments.
\end{abstract}

Keywords Internal phosphorus loading $\cdot$ Sediment anoxia $\cdot$ Shallow areas $\cdot$ Aeration

\section{Introduction}

Lakes act as traps accumulating nutrients at the bottom (Granéli 1999; Søndergaard et al. 2003). However, under certain conditions these nutrients can be recycled back to the overlying water column, resulting in adverse effects for the lake water quality. Particularly, the release of phosphorus

Olga Tammeorg

olga.tammeorg@helsinki.fi

1 Ecosystems and Environment Research Programme, Faculty of Biological and Environmental Sciences, University of Helsinki, P.O. Box 65, (Viikinkaari 1), 00014 Helsinki, Finland

2 Centre for Limnology, Estonian University of Life Sciences, 61117 Rannu, Estonia

3 Freshwater Research, 3421 Hwy 117, Baysville, ON P0B 1A0, Canada
(P) from sediments has hindered restoration of lake water quality worldwide by delaying the response to reduced nutrient loading from the catchment (i.e., external loading; Sas 1990; Jeppesen et al. 2005). Moreover, internal P loading is often regarded to have more influence on algal biomass than external loading, as it is in a more bioavailable form (Nürnberg et al. 2013a; Bormans et al. 2016). This renders lake sediments the key targets for in-lake measures to reduce phosphorus supply to phytoplankton (Bormans et al. 2016; Nürnberg and LaZerte 2016).

The transport of $\mathrm{P}$ from sediments to the overlying water column is preceded by mobilization processes. These processes have been attributed predominantly to the changes in redox conditions. At low oxygen concentrations (redox potential below $200 \mathrm{mV}$ ) the sediment iron Fe(III) is reduced to $\mathrm{Fe}$ (II) resulting in the breakdown of $\mathrm{Fe}-\mathrm{P}$ complexes with the subsequent dissolution of the associated phosphate (Mortimer 1941, 1942). The phenomenon 
has been well documented for deep stratifying lakes that display obvious periods of hypolimnetic anoxia. In shallow (unstratified) lakes, the importance of this P mobilization mechanism might be high, but would be obscured by almost continuous vertical mixing; therefore, quantifying anoxia-generated internal $\mathrm{P}$ loading is generally difficult for these lakes (Nürnberg 2004, 2009). Well-oxidized sediment surface can be a sink of $\mathrm{P}$ via sorbing settling $\mathrm{P}$ and preventing $\mathrm{P}$ of deeper sediments from escaping. However, this mechanism may lessen over diel and seasonal cycles especially in enriched systems, turning shallow sediments to an important P source (Smith et al. 2011). Moreover, even this well-oxidized sediment surface does not preclude the potential release of mobile $\mathrm{P}$ to the overlying water column due to existing gradients with high porewater concentrations compared to low $\mathrm{P}$ concentrations in the overlying water and sediment disturbances (Tammeorg et al. 2015 , 2016). The relevance of the problem is particularly high given that deep stratifying lakes may also have extensive shallow areas. Moreover, it was found recently that anoxia-generated $\mathrm{P}$ release in the hypolimnion is of minor importance in lake water quality management (Tammeorg et al. 2017).

Restoration of deep stratifying lakes has relied mostly on improving oxygen conditions of the hypolimnion (Cooke et al. 2005; Bormans et al. 2016; Visser et al. 2016). However, there is an increasing number of studies reporting only minor effects of these measures on lake water quality (Gächter and Wehrli 1998; Nürnberg et al. 2003; Liboriussen et al. 2009; Horppila et al. 2015, 2017; Kuha et al. 2016). Although lack of success can just be caused by technical deficiencies, it can also demonstrate poor understanding of the interactions between oxygen deficit, benthic P release, and water quality (Caraco et al. 1989; Golterman 2001; Prairie et al. 2002; Kopáček et al. 2005; Hupfer and Lewandowski 2008; Molot et al. 2014; Tammeorg et al. 2017).

In the current study, we demonstrate that sediment phosphorus release is of crucial importance for lake ecosystem management by investigating the theory and underlying assumptions for the practices of lake restoration by oxygen management. First, we ascertained the importance of internal P loading from shallow areas, where the lake bed sediments may be anoxic despite being overlain by mixed, aerated water in the epilimnion. Next, we compared the relationships of key water quality variables with internal $\mathrm{P}$ loading due to sediment anoxia originating solely from stratifying areas with that including the shallow areas (as defined above) for a set of Finnish lakes. At this step, we separated aeration-treated lakes from untreated stratifying lakes. Finally, we ascertained a specific combination of lake characteristics that enables us to predict internal P loading due to sediment anoxia for a broader set of lakes worldwide and linked it to the practices of aeration.

\section{Materials and methods}

\section{Study area}

We used data for 56 lakes worldwide, including those from small to large, shallow to deep and oligotrophic to highly eutrophic (presented in Supplementary Material of Tammeorg et al. 2017). Thirty-three of 42 studied stratifying lakes and 12 of 14 non-stratifying lakes had the complete set of basic lake characteristics including mean and maximum depth, catchment area and lake area size, external $P$ loading (Table 1). Twenty-five studied lakes are located in southern Finland with a range of lake area from 0.25 to $155 \mathrm{~km}^{2}$, lake mean depth from 1.1 to $21 \mathrm{~m}$, and trophic state from mesotrophic to hypertrophic. Nineteen of the Finnish lakes undergo periodic anoxia, generally in winter and in summer. Seven of them have been subjected to aeration, including Enonselkä, Tuusulanjärvi, Hormajärvi, Bodominjärvi, Mallusjärvi, Pusulanjärvi and Enäjärvi. These lakes were mainly treated by hypolimnetic aeration with Mixox-units (Water-Eco Ltd, Kuopio, Finland) that pump oxygen-rich epilimnetic water down to the hypolimnion without breaking stratification. In Tuusulanjärvi, destratification was intentionally applied since 1998 (Horppila et al. 2017). The duration of treatment application varied between lakes, being longest in case of Tuusulanjärvi and Enonselkä (Water-Eco Ltd., 2019).

\section{Internal phosphorus loading due to sediment anoxia}

The $\mathrm{P}$ loading from shallow lake areas that were overlain by mixed aerated water was determined as the difference between predicted $\left(\mathrm{IP}_{\text {pred }}\right)$ and observed $\left(\mathrm{IP}_{\mathrm{obs}}\right)$ internal P loading. $\mathrm{IP}_{\mathrm{obs}}$ is associated only with the deep

Table 1 Summary of the basic characteristics for 45 lakes (33 stratifying and 12 non-stratifying) with complete data sets (original data in Tammeorg et al. 2017)

\begin{tabular}{llllll}
\hline Variable $^{\mathrm{a}}$ & Unit & Mean & SD & Minimum & Maximum \\
\hline $\mathrm{CA}$ & $\mathrm{km}^{2}$ & 6299 & 21,626 & 1 & 122,000 \\
$\mathrm{D}$ & $\mathrm{m}$ & 9.3 & 14.0 & 1.1 & 90.0 \\
$\mathrm{D}_{\max }$ & $\mathrm{m}$ & 24.5 & 37.9 & 2.6 & 251.0 \\
$\mathrm{LA}$ & $\mathrm{km}^{2}$ & 746 & 3852 & 0.1 & 25,821 \\
$\mathrm{IF}$ & $\mathrm{mg} \mathrm{P} \mathrm{m}^{-2} \mathrm{y}^{-1}$ & 1528 & 5638 & 23 & 38,155 \\
\hline
\end{tabular}

${ }^{a}$ The variables include: catchment area (CA), mean depth (D), maximum depth $\left(\mathrm{D}_{\max }\right)$, lake area (LA), external loading of $\mathrm{P}$ (IF) 
stratifying areas, i.e. areas where anoxia is evident. $\mathrm{IP}_{\text {pred }}$ (in $\mathrm{mg} \mathrm{P} \mathrm{m}^{-2}$ per summer, thereafter $\mathrm{mg} \mathrm{P} \mathrm{m}^{-2} \mathrm{sum}^{-1}$ ), i.e., internal $P$ loading from anoxic surfaces of the entire lake (including those in both stratifying and shallow lake areas) was determined according to Eq. (1) (Nürnberg 2009):

$\mathrm{IP}_{\text {pred }}=\mathrm{AF}_{\text {pred }} \times \mathrm{RR}_{\text {pred }}$,

where $R R_{\text {pred }}$ is the $\mathrm{P}$ release rate under anoxic conditions. Anoxic sediments in eutrophic lakes release $\mathrm{P}$ at significantly higher rates than in lakes with lower trophic states (Nürnberg 1988, 1997; Carter and Dzialowski 2012), and mean values reported for the lakes worldwide $(n=6,14,40,29$ for oligoto hypertrophic lakes; Nürnberg 1997) were used as approximation, where $\mathrm{RR}_{\text {pred }}$ : for oligotrophic $0 \mathrm{mg} \mathrm{P} \mathrm{m}^{-2} \mathrm{~d}^{-1}$, mesotrophic $6.1 \mathrm{mg} \mathrm{P} \mathrm{m}^{-2} \mathrm{~d}^{-1}$, eutrophic $10.8 \mathrm{mg} \mathrm{P} \mathrm{m}^{-2} \mathrm{~d}^{-1}$ and hypertrophic lakes $25.6 \mathrm{mg} \mathrm{P} \mathrm{m}^{-2} \mathrm{~d}^{-1}$. Studied lakes were classified as oligotrophic (average epilimnetic summer $\mathrm{TP}<10 \mu \mathrm{g} / \mathrm{l})$, mesotrophic $(10<\mathrm{TP}<30 \mu \mathrm{g} / \mathrm{l})$, eutrophic $(30<\mathrm{TP}<100 \mu \mathrm{g} / \mathrm{l})$ and hypereutrophic $(>100 \mu \mathrm{g} / \mathrm{l})$ based on the criteria by Nürnberg (1996). Despite long periods and extent of anoxia, P release rates in low-productive lakes (e.g., oligotrophic lakes stained with organic acids and deep-for-area morphometries) are negligible due to a lack of reductant-soluble $\mathrm{P}$ in the sediment, or due to aluminium (Al) fluxes from watersheds ( $\mathrm{Al}$ compounds enable efficient binding of P; Kopáček et al. 2005).

$\mathrm{AF}_{\text {pred }}$ represents the sediment area potentially involved in $P$ release modeled as anoxic factor (Nürnberg 2004):

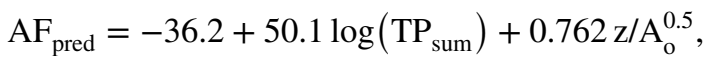

where $\mathrm{AF}_{\text {pred}}$, summer $\mathrm{AF}\left(\mathrm{d}\right.$ summer $\left.{ }^{-1}\right) ; \mathrm{z}$, mean depth $(\mathrm{m})$; $\mathrm{A}_{\mathrm{o}}$, lake surface area $\left(\mathrm{km}^{2}\right) ; \mathrm{TP}_{\text {sum }}$, epilimnetic summer concentration of TP $\left(\mu \mathrm{g}^{-1}\right)$.

The internal $P$ loads resulting from the difference between $\mathrm{IP}_{\text {pred }}$ and $\mathrm{IP}_{\text {obs }}$ can be assumed to be mediated by redox processes in the upper sediments and at the sediment-water interface of the un-stratified areas because $\mathrm{IP}_{\text {pred }}$ is based on $\mathrm{AF}_{\text {pred }}$ (Eq. 2). That difference could be slightly enhanced by potential overestimation of the release rates by the release rate model, that is based on deep-water sediments of stratified lakes. Originally, the $\mathrm{AF}_{\text {pred }}$ model was developed with data of stratifying lakes (Nürnberg 1995, 2004). However, comparisons of different internal load approaches in polymictic lakes supported the use of $\mathrm{AF}_{\text {pred }}$ with anoxic release rates for eutrophic shallow and mixed lakes (Nürnberg 2005), in which large sediment surfaces can still be anoxic and actively releasing phosphorus. In other words, $\mathrm{AF}_{\text {pred }}$ adequately quantifies the sediment area of polymictic lakes, where redox-related $\mathrm{P}$ release occurs and thus also in shallow areas (i.e. areas, in which sediments are overlain by mixed water) of stratified lakes. There is no simple experimental way of determining such an area for unstratified lakes and lake sections.

The more eutrophic a lake is, the more likely is the difference between $\mathrm{IP}_{\text {pred }}$ and $\mathrm{IP}_{\mathrm{obs}}$ because of different $P$ release rates. In oligotrophic lakes, release rate of $P$ is close to zero and there is not much contribution from either stratifying or shallow areas (despite that AF can be high), which is not the case of eutrophic lakes that have considerably higher release rates (while AF can be comparable to that in oligotrophic lakes). These relationships are important because nutrient-rich lakes are indeed the main targets in water quality management.

The values for $\mathrm{IP}_{\mathrm{obs}}$ were reported in Tammeorg et al. (2017). For the Finnish lakes, the hypolimnetic accumulation of $\mathrm{P}$ (Nowlin et al. 2005) was a measure of $\mathrm{IP}_{\mathrm{obs}}$ $\left(\mathrm{mg} \mathrm{P} \mathrm{m}^{-2}\right.$ sum $\left.^{-1}\right)$. In the rest of the lakes, an approach similar to that in Eq. (1) was used, with the difference that the factors multiplied $\left(\mathrm{RR}_{\mathrm{obs}}\right.$ and $\left.\mathrm{AF}_{\mathrm{obs}}\right)$ were measured values. $R_{\mathrm{obs}}$ is the release rate from core incubations reported in the literature for the specific lakes. Generally, the literature values for the experimentally derived $R R$ values were reported to be similar to the RR measured in situ from hypolimnetic P mass increases, and thus, applicable to whole lakes (Nürnberg 1984, 1987, 1988). $\mathrm{AF}_{\mathrm{obs}}$ is the product of the percentage of anoxic areas and duration of anoxia revealed by monitored dissolved oxygen profiles (Nürnberg 2004). In stratified lakes, sediment anoxia estimated from anoxia monitored in the water is similar to modelled anoxia, so that $\mathrm{AF}_{\text {obs }} \approx \mathrm{AF}_{\text {pred }}$. But with increasing percentage of shallow versus whole lake surface areas, the discrepancy between the AFs increases so that $\mathrm{AF}_{\mathrm{obs}} \ll \mathrm{AF}_{\text {pred }}$ in polymictic lakes. This occurs because shallow eutrophic lake sediments often exhibit narrow anoxic layers that are not measured by routine DO profile monitoring (Nürnberg 2009; Smith et al. 2011). For the lakes, in which hypolimnetic TP accumulation values were available, $\mathrm{IP}_{\mathrm{obs}}$ was divided by $\mathrm{AF}_{\mathrm{obs}}$ to obtain anoxic release rates in the stratifying areas $\left(\mathrm{mg} \mathrm{P} \mathrm{m}^{-2} \mathrm{~d}^{-1}\right)$. We did so to see how $R_{\text {obs }}$ compared with $R R_{\text {pred }}$, as two lakes of very similar $\mathrm{P}$ concentration yet fall into adjacent trophic categories might have been assigned markedly different release rates.

The differences between $\mathrm{IP}_{\text {obs }}$ and $\mathrm{IP}_{\text {pred }}$ (and contributing variables including $A F_{\text {obs }} v{ } A_{\text {pred }}$, and $R R_{\text {obs }}$ vs $\left.R_{\text {pred }}\right)$ in stratifying lakes $(n=42)$ were analysed with paired $t$ tests. Correlations between corresponding variables were described with Pearson correlation coefficients. The relationships of the key water quality variables with $\mathrm{IP}_{\mathrm{obs}}$ and $\mathrm{IP}_{\text {pred }}$ were analyzed. For that purpose, we used data for 19 stratifying Finnish lakes, as they had the complete set of potentially-dependent water quality variables (Finnish Environment Institute). Studied water quality variables included total phosphorus $\left(\mathrm{TP}_{\text {surf }}, \mathrm{TP}_{\text {bot }}\right)$ and soluble reactive 
phosphorus concentration $\left(\mathrm{SRP}_{\text {surf }}, \mathrm{SRP}_{\text {bot }}\right)$ in the surface and in near-bottom water layer $(0.5 \mathrm{~m}$ above the lake bottom) and concentration of chlorophyll $a$. Means of the whole growing season for the long-term period (1984-2014) were used.

Additionally, we studied the relationships of $\mathrm{IP}_{\mathrm{obs}}$ and $\mathrm{IP}_{\text {pred }}$ with $\mathrm{IP}_{\text {tot }}$, the total flux of sedimentary P. This internal $\mathrm{P}$ loading due to a sum of factors including sediment anoxia was calculated as a function of the difference in phosphorus retentions (Tammeorg et al. 2017). $\mathrm{IP}_{\text {tot }}$ was demonstrated to affect surface water quality (Tammeorg et al. 2017). Since seven lakes were (continuously or periodically) subject to aeration, we suggested possible implications and thus differentiated two treatments (aerated and non-aerated) while analysing relationships between IP and water quality variables. Analysis of variance was used to test whether there were significant differences between the treatments in the effect of $\mathrm{IP}_{\text {obs }}$ and $\mathrm{IP}_{\text {pred }}$ on water quality variables, and $\mathrm{IP}_{\text {tot }}$. Log- or square-root-transformations of the studied variables were used to ensure the normal distribution of residuals (by Shapiro-Wilk test).

\section{A tool for predicting internal phosphorus loading due to sediment anoxia and potential linkage to aeration effects}

To ascertain lake characteristics responsible for the $\mathrm{IP}_{\text {pred }}$, a principal component analysis (PCA) was carried out. Data for all 45 lakes having a complete set of lake characteristics were used. Principal components (PCs) were obtained as weighted linear combinations of the original variables. Original variables included the lake characteristics that were demonstrated to be of high importance for controlling lake phosphorus dynamics, i.e. maximum depth $\left(\mathrm{D}_{\max }\right)$, mean depth (D), lake area (LA), catchment area (CA), external loading of P (IF). Each characteristic was statistically standardized to have a zero mean and unit standard deviation in the set of all lakes. This approach generates principal components (PCs) as new complex (synthetic) uncorrelated factors that integrate individual characteristics. Three lakes behaved as outliers due to exceptionally large IF (Lake Pepin), LA (Lake Erie), and $\mathrm{D}, \mathrm{D}_{\max }$ (Lake Constance), and thus were excluded from the analysis. The effects of the PCs on the $\mathrm{IP}_{\text {pred }}$ were estimated by using the general multiparametrical linear model. Initially, all five PCs were used together as predictors of the $\mathrm{IP}_{\text {pred }}$ to ascertain significant PCs. After that, significant PCs were used singly as the predictors of the $\mathrm{IP}_{\text {pred }}$. The same approach has been used to describe spatial variability in $\mathrm{IP}_{\mathrm{obs}}$ (Tammeorg et al. 2017). The rationale for this approach is that variations in sediment $\mathrm{P}$ release can hardly be explained by any single lake characteristics (e.g., lake depth), as these often correlate to each other. Data on these lake characteristics are usually more easily accessed for predicting internal $\mathrm{P}$ loading, as opposed to, for example, sediment data that require much more effort and expense to collect.

Finally, we demonstrated the potential application of the dependence of $\mathrm{IP}_{\text {pred }}$ on a specific PC to lake management practice. For that, we calculated the PC values that were driving $\mathrm{IP}_{\text {pred }}$ for several lakes, of well-documented case studies of aeration treatment on water quality of Gächter and Wehrli (1998), Nürnberg et al. (2003), Schauser and Chorus (2007), Moore et al. (2012) and Kuha et al. (2016). These included Lake Jyväsjärvi (Finland), Lake Sempach (Switzerland), Lake Tegel (Germany), Lake Newman (USA) and Lake Wilcox (Canada). PC values for these lakes were calculated as a sum of products of the coefficients of the $\mathrm{IP}_{\text {pred }}$-driving-PC and standardized values of the corresponding lake characteristics. For standardization, mean values and standard deviations of the whole dataset were used. We assumed that variations in the effect of aeration treatment on lake water quality could be coupled to changes in $\mathrm{IP}_{\text {pred }}$

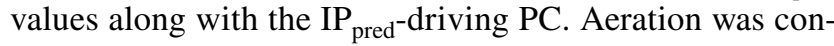
sidered to be successful when it resulted in reduced concentrations of $\mathrm{TP}_{\text {surf }}$ and $\mathrm{Chl} a$.

\section{Results}

\section{Internal phosphorus loading due to sediment anoxia and its contribution to lake water quality}

In stratifying lakes of the current study, $\mathrm{IP}_{\text {pred }}$ varied from 0 to $2117 \mathrm{mg} \mathrm{P} \mathrm{m}^{-2}$ summer $^{-1}$ (mean $404 \mathrm{mg} \mathrm{P} \mathrm{m}^{-2}$ sum $^{-1}$ ). $\mathrm{IP}_{\mathrm{obs}}$ was significantly lower (paired $t$ test, $p<0.001$; mean $197 \mathrm{mg} \mathrm{P} \mathrm{m}^{-2} \mathrm{sum}^{-1}$ ) and varied from 3 to $1578 \mathrm{mg} \mathrm{P} \mathrm{m}^{-2}$ sum $^{-1}$. However, $\mathrm{IP}_{\text {pred }}$ correlated well with $\mathrm{IP}_{\mathrm{obs}}(r=0.645, p<0.001) . \mathrm{AF}_{\text {pred }}$ values ranged from 4.9 and 82.7 day sum ${ }^{-1}$ (mean 37 day sum ${ }^{-1}$ ) and $\mathrm{AF}_{\text {obs }}$ from 1 to 72 day sum ${ }^{-1}$ (mean 24 day sum ${ }^{-1}$ ). The differences between the $\mathrm{AF}_{\text {pred }}$ and $\mathrm{AF}_{\text {obs }}$ values were statistically significant $(p=0.004)$. Release rates of $\mathrm{P}$ calculated from the in-lake observations (in situ $\mathrm{P}$ increases) increased across the trophic gradient $(p=0.009)$, being on average ( \pm standard error) $1.26 \pm 0.17,3.71 \pm 1.06,11.88 \pm 3.30$, and $12.84 \pm 3.24 \mathrm{mg} \mathrm{m}^{-2} \mathrm{~d}^{-1}$ for oligotrophic $(n=8)$, mesotrophic $(n=15)$, eutrophic $(n=12)$, and hypertrophic $(n=4)$ lakes, respectively. Despite the observed minor overlap for eutrophic and hypertrophic lakes, the values were in the same range as the values that were used in the calculation of $\mathrm{IP}_{\text {pred }}$ (i.e., release rates of $\mathrm{P}$ under anoxic conditions reported in literature for the lakes worldwide; Nürnberg 1997), underlining the importance of trophy for anoxic release of $\mathrm{P}$. 

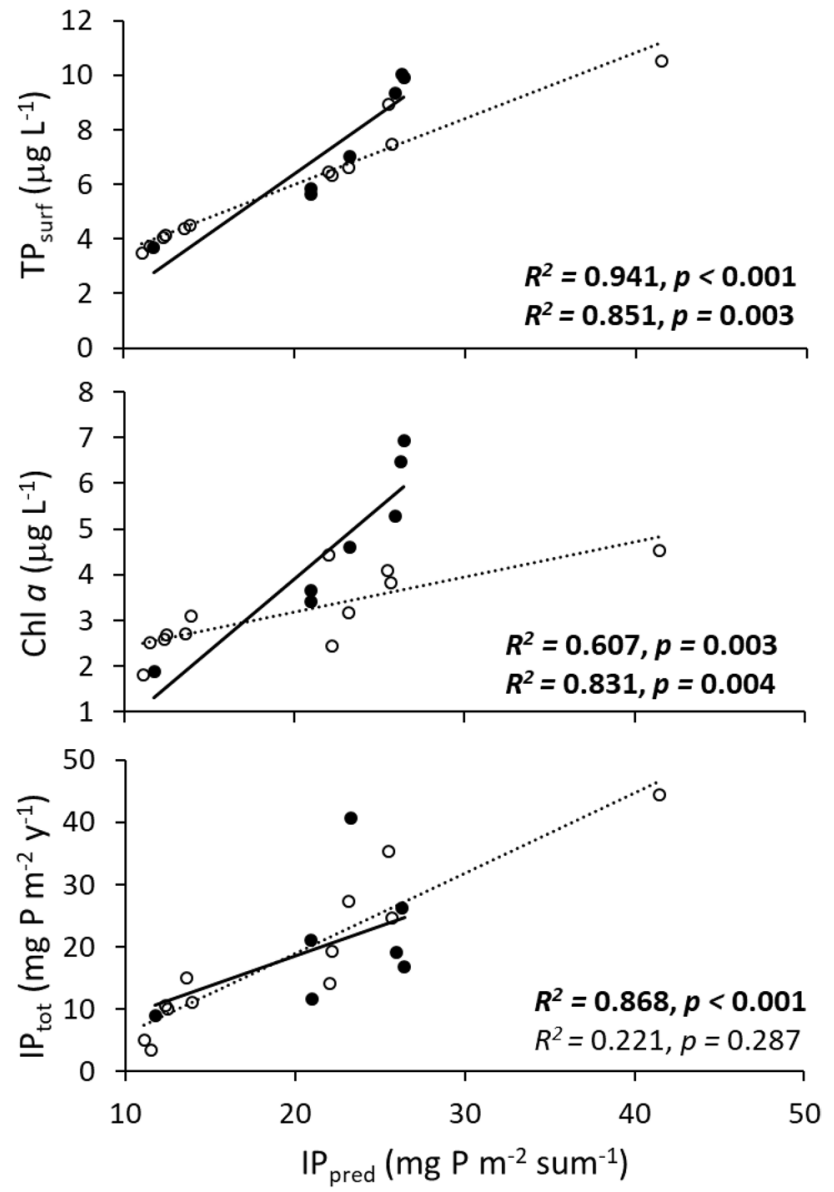

Fig. 1 The concentration of the total phosphorus in the surface water layer $\left(\mathrm{TP}_{\text {surf }}\right)$, chlorophyll $a(\mathrm{Chl} a)$ and total sedimentary $\mathrm{P}$ flux $\left(\mathrm{IP}_{\mathrm{tot}}\right)$ as a function of the internal $\mathrm{P}$ loading due to sediment anoxia from both deep and shallow areas $\left(\mathrm{IP}_{\text {pred }}\right)$ in non-aerated (open circles) and aerated (filled circles) lakes. Trends are shown for non-aerated lakes (upper $r$ and $p$ values, dashed line) and for aerated lakes (solid line). Note that square-root-transformed values for all variables are presented

In Finnish stratifying lakes, all studied water quality variables and $\mathrm{IP}_{\text {tot }}$ related significantly and positively to $\mathrm{IP}_{\text {pred }}\left(\mathrm{TP}_{\text {surf }}, \mathrm{TP}_{\text {bot }}, \mathrm{Chl} a\right.$, and $\mathrm{IP}_{\text {tot }}, p<0.001 ; \mathrm{SRP}_{\text {surf }}$, $\left.p=0.017 ; \mathrm{SRP}_{\mathrm{bot}}, p=0.032\right)$. All these relationships were also significant for a subset of non-aerated lakes, $\mathrm{IP}_{\text {pred }}$ with $\mathrm{TP}_{\text {bot }}(p<0.001), \mathrm{TP}_{\text {surf }}(p<0.001), \mathrm{SRP}_{\text {surf }}$ $(p=0.002), \operatorname{SRP}_{\mathrm{bot}}(p=0.001), \mathrm{Chl} a(p=0.003$; Fig. 1$)$ and $\mathrm{IP}_{\text {tot }}(p<0.001 ;$ Fig. 1$)$. In contrast, for aerated lakes $\mathrm{IP}_{\text {pred }}$ was only significant for $\mathrm{TP}_{\text {surf }}(p=0.003)$ and Chl $a$ $\left(p=0.004\right.$; Fig. 2). Moreover, the correlation of $\mathrm{IP}_{\text {pred }}$ with Chl $a$ was affected by treatment (aerated or not, $p=0.001$ ), being higher in aerated lakes. $\mathrm{IP}_{\mathrm{obs}}$ related significantly only to $\operatorname{TP}_{\text {bot }}(p<0.009)$. Moreover, the relationship between $\mathrm{TP}_{\mathrm{bot}}$ and $\mathrm{IP}_{\mathrm{obs}}$ was still significant $(p=0.025)$ in non-aerated lakes, while not significant in aerated lakes

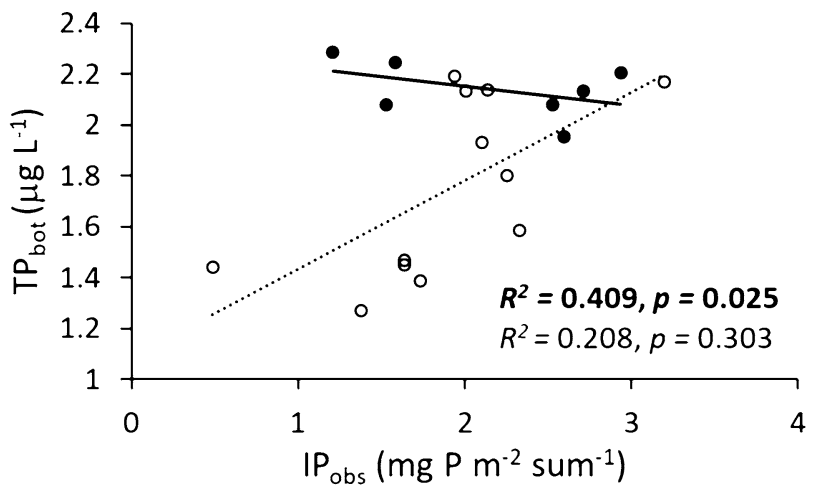

Fig. 2 The concentration of the total phosphorus in the bottom water layer $\left(\mathrm{TP}_{\mathrm{bot}}\right)$ as a function of the internal $\mathrm{P}$ loading due to sediment anoxia from deep areas $\left(\mathrm{IP}_{\mathrm{obs}}\right)$ in non-aerated (open circles) and aerated (filled circles) lakes. Trends are shown for non-aerated lakes (upper $\mathrm{r}$ and $\mathrm{p}$ values, dashed line) and for aerated lakes (solid line). Log-transformed values are presented

(Fig. 2). Noteworthy, there was no significant difference ( $t$ test) in the values of $\mathrm{IP}_{\text {pred }}$ and $\mathrm{IP}_{\text {obs }}$ between aerated (517 and $314 \mathrm{mg} \mathrm{P} \mathrm{m}^{-2}$ sum $^{-1}$ ) and non-aerated (457 and $216 \mathrm{mg} \mathrm{P} \mathrm{m}^{-2}$ sum $^{-1}$ ) lakes, possibly suggesting similarity in morphology of those lakes.

\section{Spatial variability in internal $P$ loading due to sediment anoxia, potential linkage to aeration}

The first three PCs represented about $96 \%$ of lake data variability in total (Table 2), whereby $39 \%, 38 \%$ and $18 \%$ of the lake variability were explained by PC1, PC2, and PC3, respectively. PC1 separates all the lakes along an axis largely based on lake and catchment size (Table 2). The second orthogonal axis, PC2, further separates all the lakes along

Table 2 Coefficients for calculating the five principal components (PCs) and corresponding eigenvalues of the correlation matrix calculated for 43 lakes with a full set of all eight contributing characteristics. The characteristics needed include: maximum depth $\left(\mathrm{D}_{\max }\right)$, lake area (LA), catchment area (CA), mean depth (D), external loading of $\mathrm{P}$ (IF)

\begin{tabular}{lrrrrr}
\hline Lake characteristics & PC1 & PC2 & PC3 & PC4 & \multicolumn{1}{l}{ PC5 } \\
\hline $\mathrm{D}$ & 0.353 & 0.577 & 0.267 & -0.462 & 0.558 \\
$\mathrm{D}_{\max }$ & 0.289 & 0.636 & 0.000 & 0.442 & 0.558 \\
$\mathrm{CA}$ & 0.563 & -0.387 & 0.218 & -0.480 & 0.505 \\
$\mathrm{LA}$ & 0.617 & -0.321 & 0.000 & 0.577 & -0.420 \\
$\mathrm{IF}$ & -0.305 & 0.000 & 0.933 & 0.164 & 0.000 \\
Eigenvalue & 1.936 & 1.921 & 0.919 & 0.117 & 0.107 \\
$\begin{array}{l}\text { Proportion of vari- } \\
\quad \text { ability }\end{array}$ & 0.387 & 0.384 & 0.184 & 0.023 & 0.021 \\
$\quad \begin{array}{l}\text { Cumulative propor- } \\
\quad \text { tion }\end{array}$ & 0.387 & 0.772 & 0.955 & 0.979 & 1.000 \\
\hline
\end{tabular}


an axis largely based on mean and maximum depth. The third axis separates the lakes based primarily on external $\mathrm{P}$ loading. Of the five PCs only PC3 was found to have significant effect on $\operatorname{IP}_{\text {pred }}(p<0.001)$, and there was a marginal effect of PC2 on $\operatorname{IP}_{\text {pred }}(p=0.083)$. When PCs were used as predictors in the simple linear model, only the effect of PC3 on $\mathrm{IP}_{\text {pred }}$ remained significant $\left(R^{2}=0.345, p<0.001\right.$, Fig. 3), though this component explains only a small amount of the variability among the lakes (18\%). $\mathrm{IP}_{\text {pred }}$ increased gradually with an increase in the value of PC3 (Fig. 3).

Three of five well-studied aeration-treated lakes (Jyväsjärvi, Sempach, Newman) had PC3 values similar to values for the lakes of the current study (Table 3). Lake Sempach

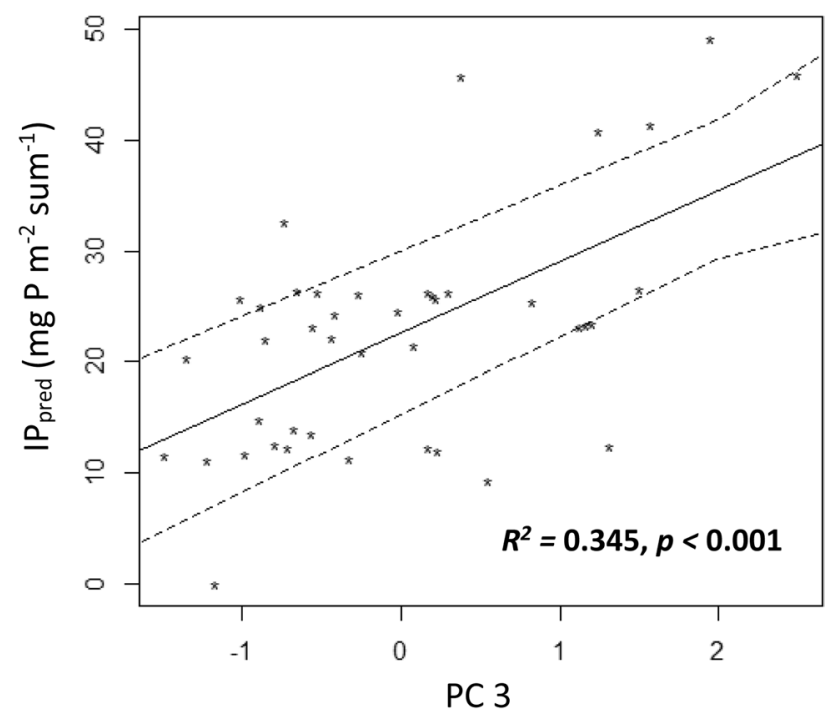

Fig. 3 Dependence of the predicted internal phosphorus loading due to anoxia (IP ${ }_{\text {pred }}$, square-root-transformed values) on the specific combination of lake characteristics represented by PC3 that is governed mainly by external $\mathrm{P}$ loading had the highest PC3 value and Lake Newman, for which positive changes in lake water quality were reported, was characterized by the lowest value of PC3. Exceptionally high values of PC 3 were ascribed to Lake Tegel and Lake Wilcox due to the large contribution of external P loading.

\section{Discussion}

\section{Internal phosphorus loading due to sediment anoxia: importance of shallow areas}

Higher values of $\mathrm{IP}_{\text {pred }}$ than $\mathrm{IP}_{\text {obs }}$ agreed with the similar trend in $\mathrm{AF}$, where $\mathrm{AF}_{\text {pred }}$ was also higher than $\mathrm{AF}_{\text {obs }}$. These findings were expected, because $\mathrm{AF}_{\text {pred }}$ and $\mathrm{IP}_{\text {pred }}$ account for larger sediment areas of $\mathrm{P}$ release that are not considered in the observed variables $\left(\mathrm{AF}_{\mathrm{obs}}\right.$ and $\left.\mathrm{IP}_{\mathrm{obs}}\right)$. A possible source of uncertainty associated with calculations of $\mathrm{IP}_{\text {pred }}$ can be an assumption that it is mainly trophic state that determines release rate of $\mathrm{P}$ under anoxic conditions of sediments in a lake as a whole. Release rates of P may be spatially variable due to sediment heterogeneity with respect to $\mathrm{P}$ concentration, temperature and general chemistry (Hilton et al. 1986; Blais and Kalff 1995). Nevertheless, the approach used to quantify $\mathrm{IP}_{\text {pred }}$ has been shown to result in estimates similar to those by other methods in shallow (mixed) lakes (Nürnberg 1987, 2005; Nürnberg et al. 2013b).

Given that $\mathrm{IP}_{\text {pred }}$ was associated with the anoxic surfaces of the entire lake basin and $\mathrm{IP}_{\mathrm{obs}}$ with those of the stratifying lake areas only, the contribution of the P release from shallow areas was $51 \%$, i.e. virtually as high as the input of deep areas (49\%). Moreover, results from Finnish lakes demonstrated that the role of shallow areas to internal P loading due to sediment anoxia is of key importance in the control of lake water quality. While $\mathrm{IP}_{\text {obs }}$ affected only $\mathrm{TP}_{\text {bot }}$, $\mathrm{IP}_{\text {pred }}$

Table 3 Case studies of aeration treated lakes with implications for water quality

\begin{tabular}{|c|c|c|c|}
\hline Lake & Type & PC3 value & Effects reported, un $(-) /$ success $(+)^{\mathrm{b}}$ \\
\hline Jyväsjärvi & Hypolimnetic oxygenation & 0.87 & $\begin{array}{l}\text { (-) Increased concentration of dissolved oxygen (DO), but no changes in trophic status } \\
\text { (based on Chl } a \text {, TP concentrations) }\end{array}$ \\
\hline Newman $^{\mathrm{a}}$ & Hypolimnetic aeration & -0.55 & (+) Increased DO, reduced internal P loading, decreased biomass of cyanobacteria \\
\hline Tegel & Hypolimnetic aeration & 8.32 & $\begin{array}{l}\text { (-) No effect on P reduction due to high sedimentation rates, no effect on redox-sensitive } \\
\text { adsorption of iron, no effect on phytoplankton or cyanobacteria }\end{array}$ \\
\hline Sempach & Hypolimnetic aeration & 1.76 & $\begin{array}{l}\text { (-) Increased DO, no change in } \mathrm{P} \text { release due to high sedimentation rates and sed/water } \\
\text { interface remaining anoxic, increased biomass of cyanobacteria }\end{array}$ \\
\hline Wilcox & $\begin{array}{l}\text { Hypolimnetic oxygenation, } \\
\text { aeration and destratifica- } \\
\text { tion }\end{array}$ & 8.41 & $\begin{array}{l}\text { (-) No changes in anoxia, higher summer and fall average concentrations of TP and } \\
\text { SRP in the epilimnion, also all measures of cyanobacteria and phytoplankton during } \\
\text { treatment years (hypolimnetic aeration/oxygenation). High cyanobacteria biomass was } \\
\text { partially due to mixing metalimnetic Planktothrix in fall and winter } 1998 \text { (Nürnberg } \\
\text { et al. 2003) }\end{array}$ \\
\hline
\end{tabular}

${ }^{a}$ In Lake Newman, a chemical treatment was also applied

${ }^{b}$ Data for the lakes except Wilcox (Nürnberg et al. 2003) and Jyväsjärvi (Kuha et al. 2016) were summarized by Bormans et al. (2016) 
accounting also for the shallow areas affected all of the studied water quality variables, including those of the surface water layer $\left(\mathrm{TP}_{\text {surf }}, \mathrm{SRP}_{\text {surf }}, \mathrm{Chl} a\right)$ that are principally important from lake water management perspective. Although thermocline erosion and entrainment of hypolimnetic P-rich water into the epilimnion can occur in lakes with less stable thermoclines (e.g., Nürnberg 1985), P released from anoxic sediments often remains entrapped in the bottom layer during most of the growing season (Marsden 1989). As a rule, it reaches surface water layer too late in the growing season, i.e. at a time when light and temperature limit algal growth (Tammeorg et al. 2017). In contrast, a continuous mixing and contact of sediment with the overlying water column ensures $\mathrm{P}$ availability for the algal growth in shallow polymictic lakes and in the shallow areas of stratified lakes. Furthermore, it is very likely that considerable implications for surface water quality are achieved through complex interactions of $\mathrm{P}$ release from anoxic sediment with other mechanisms including those of aerobic release in shallow areas. For example, sediment resuspension may considerably promote the release of $\mathrm{P}$ also from anoxic sediment by increasing the $\mathrm{P}$ concentration gradient between the sediment and overlying water column and by mixing $P$ enriched pore-water into the overlying water (Reddy et al. 1996; Tammeorg et al. 2016). The importance of other mechanisms, like ligand-exchange reactions, desorption from sediment particles, bioturbation cannot be ignored (Holmroos et al. 2009; Niemistö et al. 2012; Tammeorg et al. 2015). In support of our findings, the importance of $\mathrm{IP}_{\text {pred }}$ for water quality was comparable with that of $\mathrm{IP}_{\text {tot }}$ that was found to correlate positively with the concentrations of SRP, TP in the surface and bottom water layer and concentration of Chl $a$ (Tammeorg et al. 2017). Additionally, Finnish lakes in the current study showed significant positive relationships of $\mathrm{IP}_{\text {pred }}$ with $\mathrm{IP}_{\text {tot }}$ that was shown to originate mainly from shallow areas (Tammeorg et al. 2017).

Conclusions about the aeration treatment are limited, because of the relatively small number of treatments in the set of Finnish lakes. Further, our approach (simply creating two treatments based on being aerated or not) has limitations, as each of those cases of aeration is different in terms of methods applied, duration of aeration, and lake characteristics. For example, Lake Tuusulanjärvi has been aerated substantially longer than other lakes. Moreover, destratification (intentionally applied in Tuusulanjärvi) affects nutrient cycling in a different way compared with lakes where hypolimnetic aeration is applied (Cooke et al. 2005; Visser et al. 2016). Hence, it may be an oversimplification to attribute the different relationships of $\mathrm{IP}_{\text {pred }}$ with the water quality variables just to a treatment effect. However, similar trends of relationships of $\mathrm{IP}_{\text {pred }}$ with $\mathrm{TP}_{\text {surf }}$ and Chl $a$ for non-aerated and aerated lakes suggest little importance of the aeration-treatment for water quality. This is supported at least by the findings from Enonselkä and Tuusulanjärvi, in which aeration history has had the longest record. Although different techniques (destratification and hypolimnetic aeration) implied different impact mechanisms, no effects for the surface water quality due to aeration were reported for these two lakes. In Enonselkä, aeration has decreased $\mathrm{SRP}_{\text {bot }}$ and $\mathrm{TP}_{\text {bot }}$, but not Chl $a$. Hypolimnetic aeration decreased water column stability (apparent as increases of the hypolimnetic water temperature), resulting in increased sediment resuspension indicated by increased rates of gross sedimentation, and increased TP flux from sediments during the open-water period (Niemistö et al. 2016). Though applied intentionally, artificial destratification in Tuusulanjärvi increased near-bottom water temperature and turbulence that most likely enhanced P recycling (Horppila et al. 2017), similarly to what was observed in Enonselkä. Hence, in both cases aeration supported the supply of $\mathrm{P}$ for algal growth by facilitating $\mathrm{P}$ transport from shallow sediment areas, an important source of $\mathrm{P}$ generated by sediment anoxia. These mechanisms could possibly also explain, why we observed more pronounced relationships of $\mathrm{IP}_{\text {pred }}$ with $\mathrm{Chl} a$ in aerated compared to non-aerated lakes.

\section{Implications for lake water management by aeration treatment}

It is of crucial importance to consider also $\mathrm{P}$ generated by sediment anoxia of shallow areas in comprehensive models, as these areas are of high importance in water quality management and may affect the efficiency of aeration in stratifying lakes. Thus, determining factors behind the variation of $\mathrm{IP}_{\text {pred }}$ rather than $\mathrm{IP}_{\text {obs }}$ could be more useful for water quality management. In the current study, we found that $\mathrm{IP}_{\text {pred }}$ is driven by PC3, a specific combination of five lake characteristics. Given the importance of sediment characteristics (Hupfer and Lewandowski 2008; Randall et al. 2019), incorporating specific fractions (e.g., fractions that are commonly associated with the sediment $\mathrm{P}$ release, $\mathrm{Fe}$ content, Nürnberg 1988) may further increase the predictive power of the current model. Nevertheless, its current $R^{2}$ value was generally in a range of those that are reported for the models predicting release rates of $\mathrm{P}$ and internal $\mathrm{P}$ loading (Nürnberg et al. 1986; Nürnberg 1988; Carter and Dzialowski 2012; Tammeorg et al. 2017).

In PC3, external P loading (IF) is clearly the major constituent. In general, high IF results in the increased deposition of newly-produced P-rich material (Marsden 1989; Carey and Rydin 2011). High levels of external loading often lead to oxygen deficits that sustain the recycling of $\mathrm{P}$ to the water column (Gächter and Wehrli 1998; Moosmann et al. 2006) through the breakdown of the iron-phosphorus complexes (Mortimer 1941, 1942). Both sediment release of $P$ and oxygen depletion have been emphasized to be inevitable 
phenomena of high trophic state (Gächter and Wehrli 1998; Moosmann et al. 2006; Hupfer and Lewandowski 2008). Noteworthy, recent external load abatement is followed often by an increase in internal P loading (Sas 1990; Jeppesen et al. 2005; Søndergaard et al. 2013). Further, historical external supply of P still contributes to "legacy internal P loading" in the sediment even after IF abatement, and can be a P source for a long time (Jarvie et al. 2013; Sharpley et al. 2013).

Paradoxically, one of the most common reasons for the unsuccessful aeration projects was the insufficient control of the external P loading (Cooke et al. 2005; Bormans et al. 2016). Lake Tegel and Lake Wilcox had the greatest PC3 values, which suggests most pronounced water quality implications of the internal $\mathrm{P}$ loading due to sediment anoxia. No positive effect of aeration on $\mathrm{P}$ retention was observed in Lake Tegel, in which the improvement in lake water quality was attributed to reduced external load (Schauser and Chorus 2007). Similarly, the first priority of the external load control was emphasized for Lake Wilcox. In this lake, there was no decrease in anoxia. However, reduction in the temperature differences of the hypolimnion and epilimnion due to aeration favoured the upward transport of nutrients resulting in a TP increase in the epilimnion and a reduction in the hypolimnion (no significant change in the watercolumn averaged concentration; Nürnberg et al. 2003). Both Lake Tegel and Lake Wilcox had a PC3 value that was out of the range of the model produced with the lakes of the current study, and thus the predictions of the corresponding internal P load and its effects should be done with caution. However, Gächter and Wehrli (1998) observed no effect on P cycling in Lake Sempach, which was described by a lower value of PC3 than Lake Tegel and Lake Wilcox, despite the considerable increase in the hypolimnetic DO concentration. The authors explained the phenomenon by no cause and effect relationship between hypolimnetic oxygen deficits and $\mathrm{P}$ release, as both are inevitable in case of high trophy (Gächter and Wehrli 1998). Moreover, no additional value of aeration to the effect of external loading reduction was stressed for Jyväsjärvi (Kuha et al. 2016) even though Jyväsjärvi had a considerably lower value of PC3 (PC3 $=0.87$ ). In this lake, aeration triggered changes in the dissolved oxygen (DO) concentration in summer and winter, though these changes did not affect the trophic state of the lake. The improvements in water quality (much lower whole lake TP concentration, associated decrease of average and maximum annual phytoplankton biovolumes, elimination of considerable cyanobacteria blooms) were largely attributed to the aeration in Lake Newman (Moore et al. 2012), which had the lowest $\mathrm{PC} 3$ value $(\mathrm{PC} 3=-0.55)$ of the reported lakes. However, hypolimnetic oxygenation was applied concurrently with a chemical treatment (i.e., microfloc alum injection). Moreover, external load controls were also included as restoration activities in Lake Newman, which seem to be a more convincing explanation for lake water quality improvement. Hence, in lakes that have PC 3 value around -0.6 , the external P loading is not likely too high to cancel impacts of aeration treatments. Moreover, observations from wellknown case studies on aeration support the concept based on our results, and sediment $\mathrm{P}$ release is closely linked to external $P$ loading.

Indeed, not many studies report any effects of aeration on surface water. Moreover, there is only a limited number of lakes where aeration was successful (in terms of reduction of algal/and cyanobacterial biomass or $\mathrm{Chl} a$ concentration). For some lakes that have displayed a positive response to the treatment (Lake Amisk in Canada, Lake Serraia in Italy, Black Lake in the USA) and thus would potentially be insightful in determining the target value of PC3, data on the external $\mathrm{P}$ loading are not available. The examples we analyzed suggested higher potential for success of aeration treatments for lakes with PC 3 values around - 0.6 (i.e., comparable to that in Lake Newman), while in lakes with PC3 values about 0.9 (like in Lake Jyväsjärvi) external P loading may already abate effects of aeration. By that, we demonstrated the possible importance of the dependence of $\mathrm{IP}_{\text {pred }}$ on PC3 from lake water quality management perspective.

\section{Conclusions}

In stratifying lakes, the contribution of shallow areas to the internal P loading due to sediment anoxia is comparable to that of deep areas. The results from Finnish lakes demonstrated that this contribution is of key importance for water quality and may affect the effectiveness of aeration as a restoration measure. $\mathrm{IP}_{\text {pred }}$, internal $\mathrm{P}$ loading due to sediment anoxia of both deep and shallow areas, was found to be dependent on the specific combination of lake characteristics PC3, driven mainly by external P loading. By linking this dependence with some case studies of the aeration treatment, we suggest higher potential for success of aeration in lakes with $\mathrm{PC} 3$ values around -0.6 .

Acknowledgements Open access funding provided by University of Helsinki including Helsinki University Central Hospital. The study was supported by the Academy of Finland (project 263365) and PäijätHäme Regional Fund of Finnish Cultural Foundation.

Open Access This article is licensed under a Creative Commons Attribution 4.0 International License, which permits use, sharing, adaptation, distribution and reproduction in any medium or format, as long as you give appropriate credit to the original author(s) and the source, provide a link to the Creative Commons licence, and indicate if changes were made. The images or other third party material in this article are included in the article's Creative Commons licence, unless indicated otherwise in a credit line to the material. If material is not included in the article's Creative Commons licence and your intended use is not 
permitted by statutory regulation or exceeds the permitted use, you will need to obtain permission directly from the copyright holder. To view a copy of this licence, visit http://creativecommons.org/licenses/by/4.0/.

\section{References}

Blais JM, Kalff J (1995) The influence of lake morphometry on sediment focusing. Limnol Oceanogr 40:582-588

Bormans M, Maršálek B, Jančula D (2016) Controlling internal phosphorus loading in lakes by physical methods to reduce cyanobacterial blooms: a review. Aquat Ecol 50:407-422

Caraco NF, Cole JJ, Likens GE (1989) Evidence for sulphate-controlled phosphorus release from sediments of aquatic systems. Nature 341:316-318

Carey CC, Rydin E (2011) Lake trophic status can be determined by the depth distribution of sediment phosphorus. Limnol Oceanogr 56:2051-2063

Carter LD, Dzialowski AR (2012) Predicting sediment phosphorus release rates using landuse and water-quality data. Freshw Sci 31:1214-1222

Cooke GD, Welch EB, Peterson S, Nichols SA (2005) Restoration and management of lakes and reservoirs, 3rd edn. Taylor \& Francis, London

Gächter R, Wehrli B (1998) Ten years of artificial mixing and oxygenation: no effect on the internal phosphorus loading of two eutrophic lakes. Environ Sci Technol 32:3659-3665

Golterman HL (2001) Phosphate release from anoxic sediments or what did Mortimer really write? Hydrobiologia 450:99-106

Granéli W (1999) Internal phosphorus loading in Lake Ringsjön. Nutrient reduction and biomanipulation as tools to improve water quality: the Lake Ringsjön Story. Springer, Amsterdam, pp 19-26

Hilton J, Lishman JP, Allen PV (1986) The dominant processes of sediment distribution and focusing in a small, eutrophic, monomictic lake. Limnol Oceanogr 31:125-133

Holmroos H, Niemistö J, Weckström K, Horppila J (2009) Seasonal variation of resuspension-mediated aerobic release of phosphorus. Boreal Environ Res 14:937-946

Horppila J, Köngäs P, Niemistö J, Hietanen S (2015) Oxygen flux and penetration depth in the sediments of aerated and non-aerated lake basins. Int Rev Hydrobiol 100:106-115

Horppila J, Holmroos H, Niemistö J, Massa I, Nygrén N, Schönach P, Tammeorg O (2017) Variations of internal phosphorus loading and water quality in a hypertrophic lake during 40 years of different management efforts. Ecol Eng 103:264-274

Hupfer M, Lewandowski J (2008) Oxygen controls the phosphorus release from lake sediments-a long-lasting paradigm in limnology. Int Rev Hydrobiol 93:415-432

Jarvie HP, Sharpley AN, Spears B, Buda AR, May L, Kleinman PJ (2013) Water quality remediation faces unprecedented challenges from "legacy phosphorus". Environ Sci Technol 47:8897-8898

Jeppesen E, Søndergaard M, Jensen JP et al (2005) Lake responses to reduced nutrient loading - an analysis of contemporary long-term data from 35 case studies. Freshw Biol 50:1747-1771

Kopáček J, Borovec J, Hejzlar J, Ulrich KU, Norton SA, Amirbahman A (2005) Aluminum control of phosphorus sorption by lake sediments. Environ Sci Technol 39:8784-8789

Kuha JK, Palomäki AH, Keskinen JT, Karjalainen JS (2016) Negligible effect of hypolimnetic oxygenation on the trophic state of Lake Jyväsjärvi Finland. Limnologica 58:1-6

Liboriussen L, Søndergaard M, Jeppesen E, Thorsgaard I, Grünfeld S, Jakobsen TS, Hansen K (2009) Effects of hypolimnetic oxygenation on water quality: results from five Danish lakes. Hydrobiologia 625:157-172

Marsden MW (1989) Lake restoration by reducing external phosphorus loading: the influence of sediment phosphorus release. Freshw Biol 21:139-162

Molot LA, Watson SB, Creed IF et al (2014) A novel model for cyanobacteria bloom formation: the critical role of anoxia and ferrous iron. Freshw Biol 59:1323-1340

Moore BC, Cross BK, Beutel M, Dent S, Preece E, Swanson M (2012) Newman Lake restoration: a case study Part III. Hypolimnetic oxygenation. Lake Reserv Manag 28:311-327

Moosmann L, Gächter R, Müller B, Wüest A (2006) Is phosphorus retention in autochthonous lake sediments controlled by oxygen or phosphorus? Limnol Oceanogr 51:763-771

Mortimer CH (1941) The exchange of dissolved substances between mud and water in lakes. J Ecol 29:280-329

Mortimer CH (1942) The exchange of dissolved substances between mud and water in lakes. J Ecol 30:147-201

Niemistö J, Tamminen P, Ekholm P, Horppila J (2012) Sediment resuspension: rescue or downfall of a thermally stratified eutrophic lake? Hydrobiologia 686:267-276

Niemistö J, Köngäs P, Härkönen L, Horppila J (2016) Hypolimnetic aeration intensifies phosphorus recycling and increases organic material sedimentation in a stratifying lake: effects through increased temperature and turbulence. Boreal Environ Res 21:571-587

Nowlin WH, Evarts JL, Vanni MJ (2005) Release rates and potential fates of nitrogen and phosphorus from sediments in a eutrophic reservoir. Freshw Biol 50:301-322

Nürnberg GK (1984) The prediction of internal phosphorus load in lakes with anoxic hypolimnia. Limnol Oceanogr 29:111-124

Nürnberg GK (1985) Availability of phosphorus upwelling from ironrich anoxic hypolimnia. Arch Hydrobiol 104:459-476

Nürnberg GK (1987) A comparison of internal phosphorus loads in lakes with anoxic hypolimnia: laboratory incubations versus hypolimnetic phosphorus accumulation. Limnol Oceanogr 32:1160-1164

Nürnberg GK (1988) Prediction of phosphorus release rates from total and reductant-soluble phosphorus in anoxic lake sediments. Can J Fish Aquat Sci 45:453-462

Nürnberg GK (1995) Quantifying anoxia in lakes. Limnol Oceanogr 40:1100-1111

Nürnberg GK (1996) Trophic state of clear and colored, soft- and hardwater lakes with special consideration of nutrients, anoxia, phytoplankton and fish. Lake Reserv Manag 12:432-447

Nürnberg GK (1997) Coping with water quality problems due to hypolimnetic anoxia in Central Ontario Lakes. Water Qual Res J 32:391-405

Nürnberg GK (2004) Quantified hypoxia and anoxia in lakes and reservoirs. Sci World J 4:42-54

Nürnberg GK (2005) Quantification of internal phosphorus loading in polymictic lakes. Verh Internat Verein Limnol 29:623-626

Nürnberg GK (2009) Assessing internal phosphorus load-problems to be solved. Lake Reserv Manag 25:419-432

Nürnberg GK, LaZerte BD (2016) More than 20 years of estimated internal phosphorus loading in polymictic eutrophic Lake Winnipeg Manitoba. J Great Lake Res 42:18-27

Nürnberg GK, Shaw M, Dillon PJ, McQueen DJ (1986) Internal phosphorus load in an oligotrophic Precambrian Shield lake with an anoxic hypolimnion. Can J Fish Aquat Sci 43:574-580

Nürnberg GK, LaZerte BD, Olding DD (2003) An artificially induced Planktothrix rubescens surface bloom in a small kettle lake in Southern Ontario compared to blooms world-wide. Lake Reserv Manag 19:307-322 
Nürnberg GK, Molot LA, O’Connor E, Jarjanazi H, Winter J, Young J (2013a) Evidence for internal phosphorus loading, hypoxia and effects on phytoplankton in partially polymictic Lake Simcoe, Ontario. J Great Lake Res 39:259-270

Nürnberg GK, LaZerte BD, Loh PS, Molot LA (2013b) Quantification of internal phosphorus load in large, partially polymictic and mesotrophic Lake Simcoe, Ontario. J Great Lake Res 39:271-279

Prairie YT, de Montigny C, Del Giorgio PA (2002) Anaerobic phosphorus release from sediments: a paradigm revisited. Verh Internat Verein Limnol 27:4013-4020

Randall MC, Carling GT, Dastrup DB et al (2019) Sediment potentially controls in-lake phosphorus cycling and harmful cyanobacteria in shallow, eutrophic Utah Lake. PLoS One 14:e0212238

Reddy KR, Fisher MM, Ivanoff D (1996) Resuspension and diffusive flux of nitrogen and phosphorus in a hypereutrophic lake. J Environ Qual 25:363-371

Sas H (1990) Lake restoration by reduction of nutrient loading: expectation experiences extrapolation. Verh Internat Verein Limnol 24:247-251

Schauser I, Chorus I (2007) Assessment of internal and external lake restoration measures for two Berlin lakes. Lake Reserv Manag 23:366-376

Sharpley A, Jarvie HP, Buda A, May L, Spears B, Kleinman P (2013) Phosphorus legacy: overcoming the effects of past management practices to mitigate future water quality impairment. J Environ Qual 42:1308-1326

Smith L, Watzin MC, Druschel G (2011) Relating sediment phosphorus mobility to seasonal and diel redox fluctuations at the sediment-water interface in a eutrophic freshwater lake. Limnol Oceanogr 56:2251-2264
Søndergaard M, Jensen JP, Jeppesen E (2003) Role of sediment and internal loading of phosphorus in shallow lakes. Hydrobiologia 506:135-145

Søndergaard M, Bjerring R, Jeppesen E (2013) Persistent internal phosphorus loading during summer in shallow eutrophic lakes. Hydrobiologia 710:95-107

Tammeorg O, Horppila J, Laugaste R, Haldna M, Niemistö J (2015) Importance of diffusion and resuspension for phosphorus cycling during the growing season in large, shallow Lake Peipsi. Hydrobiologia 760:133-144

Tammeorg O, Horppila J, Tammeorg P, Haldna M, Niemistö J (2016) Internal phosphorus loading across a cascade of three eutrophic basins: a synthesis of short- and long-term studies. Sci Total Environ 572:943-954

Tammeorg O, Möls T, Niemistö J, Holmroos H, Horppila J (2017) The actual role of oxygen deficit in the linkage of the water quality and benthic phosphorus release: potential implications for lake restoration. Sci Total Environ 599:732-738

Visser PM, Ibelings BW, Bormans M, Huisman J (2016) Artificial mixing to control cyanobacterial blooms: a review. Aquat Ecol 50:423-441

Publisher's Note Springer Nature remains neutral with regard to jurisdictional claims in published maps and institutional affiliations. 